Revista Eletrônica de Direito Processual - REDP.

Rio de Janeiro. Ano 15. Volume 22. Número 2. Maio a Agosto de 2021

Periódico Quadrimestral da Pós-Graduação Stricto Sensu em Direito Processual da UERJ

Patrono: José Carlos Barbosa Moreira (in mem.). ISSN 1982-7636. pp. 619-647

www.redp.uerj.br

\title{
TRÊS PONDERAÇÕES PARA DEFENDER A DISPENSA DA GARANTIA DO \\ JUÍZO NOS EMBARGOS À EXECUÇÃO FISCAL: CRÍTICAS AO POSICIONAMENTO DO STJ ${ }^{1}$
}

\section{THREE ARGUMENTS TO DEFEND THE GUARANTEE OF JUDGMENT IN EMBARGOES ON TAX ENFORCEMENT: CRITICISTS TO THE STJ'S POSITIONING}

Rosalina Moitta Pinto da Costa

Doutora em Direito das Relações Sociais (PUC/SP). Mestre em Direito Agrário (UFPA). Professora permanente do Programa de PósGraduação Stricto Sensu em Direito da Universidade Federal do Pará (PPGD-UFPA). Coordenadora do Grupo de Pesquisa “Inovações no Processo Civil" (UFPA/CNPQ). Belém/Pará. $\quad$ E-mail: rosalina.costa@hotmail.com.

RESUMO: Esta pesquisa visa mostrar que o STJ, exigindo a garantia do juízo para o processamento dos embargos, opõe-se à carga valorativa das normas constitucionais do CPC de 2015, à Súmula Vinculante 28 do STF e ao princípio da especialidade. Com base em pesquisa bibliográfica e na jurisprudência do STJ, inicialmente se constata que a opção do legislador pela sistemática de defesa na execução fiscal não decorre das particularidades da relação entre o fisco e o contribuinte. A seguir, demonstra-se que o posicionamento do STJ quanto à sistemática dos recursos repetitivos, à luz do CPC de 1973, não se coaduna com os princípios constitucionais do CPC de 2015. Ao final, conclui-se que a exigência da garantia do juízo contrasta com a Súmula Vinculante 28 do STF, uma vez que se devem

\footnotetext{
${ }^{1}$ Artigo recebido em 05/06/2020 e aprovado em 14/03/2021.
} 
Revista Eletrônica de Direito Processual - REDP.

Rio de Janeiro. Ano 15. Volume 22. Número 2. Maio a Agosto de 2021

Periódico Quadrimestral da Pós-Graduação Stricto Sensu em Direito Processual da UERJ

Patrono: José Carlos Barbosa Moreira (in mem.). ISSN 1982-7636. pp. 619-647

www.redp.uerj.br

aplicar aos embargos à execução fiscal as mesmas consequências jurídicas da ação anulatória.

PALAVRAS-CHAVE: Embargos à execução fiscal. Ação anulatória. Súmula Vinculante 28. Neoprocessualismo. Princípio da especialidade.

ABSTRACT: This research aims to demonstrate that the positioning of the STJ, demanding the guarantee of judgment for the processing of embargoes, goes against the valuation load of the constitutional rules brought with the CPC of 2015, the positioning of the Binding Precedent 28 of the STF and the principle of specialty. Using bibliographic research and the STJ's jurisprudence as a methodological option, the study begins by demonstrating that the legislator's option for the defense system in tax enforcement does not arise from the particularities of the relationship between the tax authorities and the taxpayer. Next, it is shown that the positioning based on the STJ by the systematic of repetitive appeals, under the aegis of the CPC of 1973, is not consistent with the constitutional principles foreseen in the CPC of 2015. In the end, it is concluded that the guarantee requirement of the court is in opposition to the position of the Supreme Court's Binding Precedent 28, since the same legal consequences of the annulment action must apply to embargoes on tax enforcement.

KEYWORDS: Tax enforcement embargoes. Annulment action. Binding legal precedent 28. Neoprocessualism. Principle of specialty.

\section{INTRODUÇÃO}

De acordo com a disposição expressa no artigo 16 , § $1 .^{\circ}$, da Lei n. ${ }^{\circ} 6.830$, de 22 de setembro de 1980, a chamada Lei de Execuções Fiscais (LEF), os embargos à execução fiscal somente podem ser manejados após a garantia do juízo.

A aplicabilidade de referida norma tem sido questionada pela doutrina desde 2006, quando a Lei n. ${ }^{\circ}$ 11.382, de 6 de dezembro desse ano, alterou o artigo 736 do Código de 
Revista Eletrônica de Direito Processual - REDP.

Rio de Janeiro. Ano 15. Volume 22. Número 2. Maio a Agosto de 2021

Periódico Quadrimestral da Pós-Graduação Stricto Sensu em Direito Processual da UERJ

Patrono: José Carlos Barbosa Moreira (in mem.). ISSN 1982-7636. pp. 619-647

www.redp.uerj.br

Processo Civil (CPC) de 1973, dispensando a garantia do juízo para a oposição de embargos; mais recentemente, a sistemática foi mantida pelo artigo 914 do CPC de 2015, em razão da carga valorativa das normas constitucionais.

Embora o Superior Tribunal de Justiça (STJ) já se tenha posicionado pela aplicabilidade do referido artigo $16, \S 1 .^{\circ}$, da LEF, em atenção ao princípio da especialidade da LEF, afirmando que a redação do CPC não se aplica às execuções fiscais diante da presença do referido dispositivo, que exige expressamente a garantia para a apresentação dos embargos à execução fiscal, vários são os fundamentos para se defender a incongruência dessa posição do STJ.

Esta pesquisa visa demonstrar que o posicionamento assentado em 2013 no STJ, sob a sistemática dos recursos repetitivos, e mantido após o advento do Código de Processo Civil de 2015, exigindo a garantia do juízo para o processamento dos embargos, vai de encontro ao princípio da especialidade, à carga valorativa das normas constitucionais trazidas com o CPC de 2015 e, por fim, ao posicionamento da Súmula Vinculante 28 do Supremo Tribunal Federal (STF).

Inicia-se o estudo enfrentando o fundamento norteador da posição assentada na Corte Superior, demonstrando-se a inaplicabilidade do princípio da especialidade no que tange à defesa mediante os embargos, uma vez que a opção do legislador pela sistemática de defesa na execução fiscal não decorre das particularidades da relação entre o físco e o contribuinte. A seguir, demonstra-se que o referido entendimento não se coaduna com os princípios constitucionais previstos no CPC de 2015, ignorando os fenômenos do neoconstitucionalismo e do neoprocessualismo albergados na nova sistemática processual.

Ao final, conclui-se que a posição do STJ não apenas viola o princípio da especialidade, a garantia do direito de defesa e o princípio constitucional de acesso à justiça, mas, principalmente, opõe-se ao posicionamento da Súmula Vinculante 28 do STF, uma vez que se devem aplicar aos embargos à execução fiscal as mesmas consequências jurídicas da ação anulatória.

O trabalho utiliza como opção metodológica a pesquisa bibliográfica e a jurisprudência do STJ. 
Revista Eletrônica de Direito Processual - REDP.

Rio de Janeiro. Ano 15. Volume 22. Número 2. Maio a Agosto de 2021

Periódico Quadrimestral da Pós-Graduação Stricto Sensu em Direito Processual da UERJ

Patrono: José Carlos Barbosa Moreira (in mem.). ISSN 1982-7636. pp. 619-647

www.redp.uerj.br

\section{A DECISÃO DO STJ: INCONGRUÊNCIA?}

De acordo com a disposição expressa no artigo 16, § 1. ${ }^{\circ}$, da Lei de Execuções Fiscais $^{2}$, os embargos à execução fiscal somente podem ser manejados após a garantia do juízo. Tal dispositivo conflita com as normas do Código de Processo Civil que, desde 2006, com a alteração efetuada pela Lei n. ${ }^{\circ} 11.382$ no artigo 736 do CPC, passou a dispensar a garantia como condicionante dos embargos. Esse preceito foi confirmado pelo artigo 914 do CPC de 2015 que assim traz: "O executado, independentemente de penhora, depósito ou caução, poderá se opor à execução por meio de embargos”.

Contudo, o STJ, em julgamento do REsp 1272827/PE ${ }^{3}$, em 2013, analisado sob a sistemática dos recursos repetitivos (art. 543-C do CPC de 1973), decidiu pela manutenção da exigência da garantia para o processamento dos embargos por se tratar de norma específica, não derrogada pelo CPC, em acórdão assim ementado:

PROCESSUAL CIVIL. TRIBUTÁRIO. RECURSO REPRESENTATIVO DA
CONTROVÉRSIA. ART. 543-C, DO CPC. APLICABILIDADE DO ART. 739-
A, $\S 1^{\circ}$, DO CPC ÂS EXECUÇÕES FISCAIS. NECESSIDADE DE
GARANTIA DA EXECUÇÃO E ANÁLISE DO JUIZ A RESPEITO DA
RELEVÂNCIA DA ARGUMENTAÇÃO (FUMUS BONI JURIS) E DA
OCORRÊNCIA DE GRAVE DANO DE DIFÍCIL OU INCERTA
REPARAÇÃO (PERICULUM IN MORA) PARA A CONCESSÃO DE EFEITO
SUSPENSIVO AOS EMBARGOS DO DEVEDOR OPOSTOS EM
EXECUÇÃO FISCAL.
1. A previsão no ordenamento jurídico pátrio da regra geral de atribuição de
efeito suspensivo aos embargos do devedor somente ocorreu com o advento da
Lei n. 8.953, de 13 de dezembro de 1994, que promoveu a reforma do Processo
de Execução do Código de Processo Civil de 1973 (Lei n. 5.869, de 11 de janeiro
de 1973 - CPC/73), nele incluindo o $1^{\circ}$ do art. 739 , e o inciso I do art. 791 .
2. Antes dessa reforma, e inclusive na vigência do Decreto-lei n. 960 , de 17 de
dezembro de 1938, que disciplinava a cobrança judicial da dívida ativa da
Fazenda Pública em todo o território nacional, e do Código de Processo Civil de
1939 (Decreto-lei n. 1.608/39), nenhuma lei previa expressamente a atribuição,
em regra, de efeitos suspensivos aos embargos do devedor, somente admitindo-
os excepcionalmente. Em razão disso, o efeito suspensivo derivava de
construção doutrinária que, posteriormente, quando suficientemente

\footnotetext{
2 “Art. 16 - O executado oferecerá embargos, no prazo de 30 (trinta) dias, contados: I - do depósito; II - da juntada da prova da fiança bancária ou do seguro garantia; (Redação dada pela Lei $n^{\circ} 13.043$, de 2014); III da intimação da penhora. § $1^{\circ}$ - Não são admissíveis embargos do executado antes de garantida a execução".

3 " "...] Em atenção ao princípio da especialidade da LEF, mantido com a reforma do CPC/73, a nova redação do art. 736, do CPC dada pela Lei n. 11.382/2006 - artigo que dispensa a garantia como condicionante dos embargos - não se aplica às execuções fiscais diante da presença de dispositivo específico, qual seja o art. 16, $\S 1^{\circ}$ da Lei n. 6.830/80, que exige expressamente a garantia para a apresentação dos embargos à execução fiscal [...]" (STJ (1. Seção). REsp 1.272.827/PE. Relator: Min. Mauro Campbell Marques. Julgado em: 22/05/2013. DJe 31/05/2013).
} 
Revista Eletrônica de Direito Processual - REDP.

Rio de Janeiro. Ano 15. Volume 22. Número 2. Maio a Agosto de 2021

Periódico Quadrimestral da Pós-Graduação Stricto Sensu em Direito Processual da UERJ

Patrono: José Carlos Barbosa Moreira (in mem.). ISSN 1982-7636. pp. 619-647

www.redp.uerj.br

amadurecida, culminou no projeto que foi convertido na citada Lei n. 8.953/94, conforme o evidencia sua Exposição de Motivos - Mensagem n. 237, de 7 de maio de 1993, DOU de 12.04.1994, Seção II, p. 1696.

3. Sendo assim, resta evidente o equívoco da premissa de que a LEF e a Lei n. 8.212/91 adotaram a postura suspensiva dos embargos do devedor antes mesmo de essa postura ter sido adotada expressamente pelo próprio CPC/73, com o advento da Lei n. 8.953/94, fazendo tábula rasa da história legislativa.

4. Desta feita, à luz de uma interpretação histórica e dos princípios que nortearam as várias reformas nos feitos executivos da Fazenda Pública e no próprio Código de Processo Civil de 1973, mormente a eficácia material do feito executivo, a primazia do crédito público sobre o privado e a especialidade das execuções fiscais, é ilógico concluir que a Lei n. 6.830 de 22 de setembro de 1980 - Lei de Execuções Fiscais - LEF e o art. 53, § $4^{\circ}$ da Lei n. 8.212, de 24 de julho de 1991, foram em algum momento ou são incompatíveis com a ausência de efeito suspensivo aos embargos do devedor. Isto porque quanto ao regime dos embargos do devedor invocavam - com derrogações específicas sempre no sentido de dar maiores garantias ao crédito público - a aplicação subsidiária do disposto no $\mathrm{CPC} / 73$ que tinha redação dúbia a respeito, admitindo diversas interpretações doutrinárias.

5. Desse modo, tanto a Lei n. 6.830/80 - LEF quanto o art. 53, $\S 4^{\circ}$ da Lei n. 8.212/91 não fizeram a opção por um ou outro regime, isto é, são compatíveis com a atribuição de efeito suspensivo ou não aos embargos do devedor. Por essa razão, não se incompatibilizam com o art. 739-A do CPC/73 (introduzido pela Lei 11.382/2006) que condiciona a atribuição de efeitos suspensivos aos embargos do devedor ao cumprimento de três requisitos: apresentação de garantia; verificação pelo juiz da relevância da fundamentação (fumus boni juris) e perigo de dano irreparável ou de difícil reparação (periculum in mora).

6. Em atenção ao princípio da especialidade da LEF, mantido com a reforma do CPC/73, a nova redação do art. 736, do CPC dada pela Lei n. 11.382/2006 artigo que dispensa a garantia como condicionante dos embargos - não se aplica às execuções fiscais diante da presença de dispositivo específico, qual seja o art. 16 , $\S 1^{\circ}$ da Lei n. 6.830/80, que exige expressamente a garantia para a apresentação dos embargos à execução fiscal.

7. Muito embora por fundamentos variados - ora fazendo uso da interpretação sistemática da LEF e do CPC/73, ora trilhando o inovador caminho da teoria do "Diálogo das Fontes", ora utilizando-se de interpretação histórica dos dispositivos (o que se faz agora) - essa conclusão tem sido a alcançada pela jurisprudência predominante, conforme ressoam os seguintes precedentes de ambas as Turmas deste Superior Tribunal de Justiça. Pela Primeira Turma: AgRg no Ag 1381229/PR, Primeira Turma, Rel. Min. Arnaldo Esteves Lima, julgado em 15.12.2011; AgRg no REsp 1.225.406/PR, Primeira Turma, Rel. Min. Hamilton Carvalhido, julgado em 15.02.2011; AgRg no REsp 1.150.534/MG, Primeira Turma, Rel. Min. Benedito Gonçalves, julgado em 16.11.2010; AgRg no Ag 1.337.891/SC, Primeira Turma, Rel. Min. Luiz Fux, julgado em 16.11.2010; AgRg no REsp 1.103.465/RS, Primeira Turma, Rel. Min. Francisco Falcão, julgado em 07.05.2009. Pela Segunda Turma: AgRg nos EDcl no Ag n. 1.389.866/PR, Segunda Turma, Rei. Min. Humberto Martins, DJe de 21.9.2011; REsp, n. 1.195.977/RS, Segunda Turma, Rei. Min. Mauro Campbell Marques, julgado em 17/08/2010; AgRg no Ag n. 1.180.395/AL, Segunda Turma, Rei. Min. Castro Meira, DJe 26.2.2010; REsp, n, 1.127.353/SC, Segunda Turma, Rei. Min. Eliana Calmon, DJe 20.11.2009; REsp, 1.024.128/PR, Segunda Turma, Rei. Min. Herman Benjamin, DJe de 19.12.2008.

8. Superada a linha jurisprudencial em sentido contrário inaugurada pelo REsp. n. 1.178.883/MG, Primeira Turma, Rel. Min. Teori Albino Zavascki, julgado em 
Revista Eletrônica de Direito Processual - REDP.

Rio de Janeiro. Ano 15. Volume 22. Número 2. Maio a Agosto de 2021

Periódico Quadrimestral da Pós-Graduação Stricto Sensu em Direito Processual da UERJ

Patrono: José Carlos Barbosa Moreira (in mem.). ISSN 1982-7636. pp. 619-647

wWW.redp.uerj.br

20.10.2011 e seguida pelo AgRg no REsp 1.283.416/AL, Primeira Turma, Rel. Min. Napoleão Nunes Maia Filho, julgado em 02.02.2012; e pelo REsp 1.291.923/PR, Primeira Turma, Rel. Min. Benedito Gonçalves, julgado em 01.12.2011. [... $]^{4}$.

No referido julgamento, o STJ reformou a decisão do Tribunal de origem, decidindo que a atribuição de efeito suspensivo aos embargos do devedor está condicionada ao cumprimento dos três requisitos legais: apresentação de garantia, verificação pelo Juiz da relevância da fundamentação e perigo de dano irreparável ou de difícil reparação. Admitiu, portanto, que o artigo 739-A do CPC/1973 aplica-se às execuções fiscais ${ }^{5}$, mas, em contrapartida, decidiu que o artigo 736 do CPC/1973 - que dispensa a garantia como condicionante dos embargos - não se aplica à LEF, uma vez que, nesse tópico, há dispositivo específico - artigo $16, \S 1 .^{\circ}-$, o qual exige expressamente a garantia para a apresentação dos embargos.

Afastou a Corte Superior a corrente jurisprudencial minoritária, que se formara naquela Corte, cuja tese defendia que, sendo inaplicável o artigo 736 do CPC/1973 - que retirou dos embargos a exigência prévia de garantia em juízo -, também deveria ser

\footnotetext{
${ }^{4}$ STJ (1. Seção). REsp 1272827/PE. Relator: Min. Mauro Campbell Marques. Julgado em: 22/05/2013. DJe 31/05/2013.

5 “AGRAVO INTERNO. TRIBUTÁRIO E PROCESSUAL CIVIL. EMBARGOS À EXECUÇÃO FISCAL. EFEITO SUSPENSIVO. APLICABILIDADE DO ART. 739-A DO CPC. RESP. 1.272.827/PE, REL. MIN. MAURO CAMPBELL MARQUES, DJE 31.5.2013, SUBMETIDO AO RITO DO ART. 543-C DO CPC. AGRAVO INTERNO A QUE SE NEGA PROVIMENTO. 1. Esta Corte Superior, no julgamento do Recurso Especial 1.272.827/PE, Rel. Min. MAURO CAMPBELL MARQUES, DJe 31.5.2013, submetido ao rito do art. 543-C do CPC, pacificou o entendimento de que o art. 739-A do CPC se aplica às execuções fiscais, assim, a atribuição de efeito suspensivo aos embargos do devedor está condicionada ao cumprimento dos três requisitos legais: apresentação de garantia; verificação pelo Juiz da relevância da fundamentação e perigo de dano irreparável ou de difícil reparação. 2. Hipótese em que o Tribunal de origem consignou, expressamente, que: No presente caso, denota-se não terem sido preenchidos, a priori, os requisitos legais a ensejar a suspensão da execução fiscal, porquanto não houve o requerimento, e ainda, a alienação dos bens penhorados não configura perigo de grave dano ao executado, pois a execução visa à expropriação destes bens (fls. 70) [...]" (STJ (1. Turma). AgInt no AREsp 888.270/SP. Relator: Min. Napoleão Nunes Maia Filho. Julgado em: 08/11/2016. DJe 24/11/2016); "PROCESSUAL CIVIL. AGRAVO INTERNO NO RECURSO ESPECIAL. EMBARGOS À EXECUÇÃO FISCAL. AUSÊNCIA DE REQUISITOS PARA A CONCESSÃO DE EFEITO SUSPENSIVO. 1. A atribuição de efeito suspensivo aos embargos à execução exige, além da garantia, a presença dos juízos de relevância da argumentação (fumus boni juris) e perigo de dano irreparável ou de difícil reparação (periculum in mora), ambos ausentes na espécie. 2. Dessa forma, o apelo não supera o conhecimento, pois, no âmbito do recurso especial, não se permite o reexame dos requisitos da fumaça do bom direito e do perigo na demora para o deferimento da medida liminar pelo Juízo de origem, seja em razão do óbice constante da Súmula 7/STJ, seja pela incidência do disposto no enunciado da Súmula 735/STF, respectivamente: 'A pretensão de simples reexame de prova não enseja recurso especial.'; 'Não cabe recurso extraordinário contra acórdão que defere medida liminar.' 3. Agravo interno a que se nega provimento" (STJ (2. Turma). AgInt no REsp 1815546/AM. Relator: Min. Og Fernandes. Julgado em: 19/11/2019. DJe 26/11/2019).
} 
Revista Eletrônica de Direito Processual - REDP.

Rio de Janeiro. Ano 15. Volume 22. Número 2. Maio a Agosto de 2021

Periódico Quadrimestral da Pós-Graduação Stricto Sensu em Direito Processual da UERJ

Patrono: José Carlos Barbosa Moreira (in mem.). ISSN 1982-7636. pp. 619-647

www.redp.uerj.br

inaplicável a norma $\S 1 .^{\circ}$ do artigo 739-A do CPC/1973 - que prevê que a outorga de efeito suspensivo aos embargos supõe que a execução já esteja garantida por penhora, depósito ou caução suficientes, além de outros requisitos ${ }^{6}{ }^{7}$. Embora referida tese não seja a defendida neste trabalho, o que se busca enfatizar é o argumento que a sustenta: o legislador associou uma situação à outra, isto é, se é (in)aplicável o artigo 736 do CPC/1973, que retirou dos embargos a exigência prévia de garantia em juízo, também deve ser (in)aplicável a norma do $§ 1 .^{\circ}$ do artigo 739-A do CPC/1973.

A decisão do referido acórdão do STJ, como se vê, foi em sentido diverso.

Afirmou o STJ que a nova sistemática dos embargos prevista na Lei $\mathrm{n}{ }^{\circ}$ 11.382/2006 não é aplicável "em bloco", devendo-se cindir as aplicações do artigo 736 e do artigo 739-A do CPC/1973 (ambos na forma da Lei n. ${ }^{\circ}$ 11.382/2006) no âmbito da LEF. No voto do ministro, está consignado que a LEF e a Lei n. $^{\circ}$ 8.212/1991 não se manifestaram a respeito do efeito suspensivo dos embargos porque se tratava de questão em aberto no CPC/1973, razão pela qual, nessa matéria, deve-se dar a aplicação do texto do CPC referente aos embargos e à excepcionalidade das situações que ensejam a suspensão do processo (art. 739-A do CPC/1973). Em outra ponta, ficou afastada a aplicação nas execuções fiscais do artigo 736 do CPC/1973, na redação dada pela Lei n. ${ }^{\circ}$ 11.382/2006, que exime o executado de garantir o juízo para opor-se à execução por meio de embargos porque, nesse ponto, a LEF não é silente, estatuindo em seu artigo $16, \S 1$. $^{\circ}$ : "Não são admissíveis embargos do executado antes de garantida a execução".

Essa posição foi mantida pelo STJ mesmo com o advento do CPC de 2015 (art. 914), decidindo a Corte Superior que a dispensa da garantia do juízo para a oposição de embargos, prevista no $\mathrm{CPC}$, não se aplica às execuções fiscais diante da presença de

\footnotetext{
${ }^{6}$ STJ (1. Turma). REsp. 1.178.883/MG. Relator: Min. Teori Albino Zavascki. Julgado em: 20/10/2011.

${ }^{7}$ No mesmo sentido do REsp. 1.178.883/MG, tese já superada pelo STJ: “[...] INAPLICABILIDADE DO ART. 739-A DO CPC. GARANTIDA A EXECUÇÃO POR PENHORA [...]. A decisão ora recorrida negou provimento a Recurso Especial, mantendo o acórdão do Tribunal de origem, sob o fundamento de que a Lei de Execução Fiscal é norma específica e disciplina, ainda que indiretamente, o efeito suspensivo aos embargos oferecidos em execuções fiscais, desde que oferecida garantia e aceita pela Fazenda Nacional. [...]" (STJ (1. Turma). AgRg no REsp 1283416/AL. Relator: Min. Napoleão Nunes Maia Filho. Julgado em: 02/02/2012. DJe 09/02/2012). Também nesse mesmo sentido, tese já superada: STJ (1. Turma). AgRg no REsp 1.283.416/AL. Relator: Min. Napoleão Nunes Maia Filho. Julgado em: 02/02/2012; STJ (1. Turma). REsp 1.291.923/PR. Relator: Min. Benedito Gonçalves. Julgado em: 01/12/2011.
} 
Revista Eletrônica de Direito Processual - REDP.

Rio de Janeiro. Ano 15. Volume 22. Número 2. Maio a Agosto de 2021

Periódico Quadrimestral da Pós-Graduação Stricto Sensu em Direito Processual da UERJ

Patrono: José Carlos Barbosa Moreira (in mem.). ISSN 1982-7636. pp. 619-647

www.redp.uerj.br

dispositivo específico - o artigo $16, \S 1 .^{\circ}$, da Lei n. ${ }^{\circ} 6.830 / 1980$, que exige expressamente a garantia para a apresentação dos embargos à execução fiscal ${ }^{8}$.

Assim, para admitir a exigência da garantia da execução no processamento dos embargos à execução, aplica-se a regra da especialidade do artigo 16 da LEF, mas, para exigir a atribuição do efeito suspensivo, deve-se aplicar o CPC, exigindo-se, além da garantia do juiz, que o executado demonstre a relevância de seus argumentos (fumus boni juris) e comprove que o prosseguimento da execução poderá causar-lhe dano de difícil ou incerta reparação (periculum in mora), conforme o exige o artigo 739-A, $\S 1 .^{\circ}$, do CPC/1973, incluído pela Lei n. ${ }^{\circ}$ 11.382/2006.

Data venia, fazem-se necessárias algumas ponderações sobre a posição do STJ.

O efeito suspensivo é apenas um dos aspectos da estrutura jurídica dos embargos do devedor, não podendo ser compreendido fora do contexto integral desse instituto. A opção do legislador de dar ou não efeito suspensivo aos embargos está diretamente associada à da exigência de prévia garantia do juízo. Tanto isso é verdade que, quando a Lei n. ${ }^{\circ}$ 11.362/2006 retirou dos embargos o efeito suspensivo automático, como regra (art. 739-A do CPC/1973), incontinenti retirou também desses embargos a exigência da prévia garantia de juízo (art. 736 do CPC/1973), isto é, os embargos não têm efeito suspensivo automático,

\footnotetext{
8 “....] EXECUÇÃO FISCAL. EMBARGOS À EXECUÇÃO. GARANTIA DO JUÍZO. NECESSIDADE. PREVISÃO ESPECÍFICA. LEI 6.830/1980. [...] A jurisprudência do STJ é no sentido de que, em sede de execução fiscal, a oposição dos embargos depende de garantia do juízo, nos termos do art. 16 da Lei 6.830/1980, não afetado pela alteração do art. 736 do CPC/1973, a teor do julgamento proferido no REsp 1.272.827/PE, Rel. Ministro Mauro Campbell Marques, submetido ao rito do art. 543-C do CPC/1973. 2. No julgamento do REsp 1.127.815/SP, sob o rito do art. 543-C do CPC/1973, esta Corte consolidou o entendimento de que "não se deve obstar a admissibilidade ou apreciação dos embargos à execução pelo simples fato de que o valor do bem constrito é inferior ao valor exequendo, devendo o juiz proceder à intimação do devedor para reforçar a penhora"” (STJ (1. Turma). AgInt no REsp 1699802/RJ. Relator: Min. Benedito Gonçalves. Julgado em: 21/03/2019. DJe 26/03/2019); "PROCESSUAL CIVIL. EMBARGOS À EXECUÇÃO FISCAL. GARANTIA DO JUÍZO. PREVALÊNCIA DAS DISPOSIÇÕES DA LEF SOBRE O CPC. 1. Discute-se nos autos a possibilidade de oposição de Embargos à Execução Fiscal sem garantia do juízo nos casos de devedor hipossuficiente. 2. 'Em atenção ao princípio da especialidade da LEF, mantido com a reforma do CPC/73, a nova redação do art. 736, do CPC dada pela Lei n. 11.382/2006 - artigo que dispensa a garantia como condicionante dos embargos - não se aplica às execuções fiscais diante da presença de dispositivo específico, qual seja o art. $16, \S 1^{\circ}$ da Lei n. 6.830/80, que exige expressamente a garantia para a apresentação dos embargos à execução fiscal"” (STJ (1. Seção). REsp 1.272.827/PE. Relator: Min. Mauro Campbell Marques. DJe 31.5.2013). Cf. ainda: STJ (2. Turma). AgRg no REsp 1516732/TO. Relator: Min. Herman Benjamin. Julgado em 26/05/2015. DJe 05/08/2015; STJ (1. Seção). REsp 1.272.827/PE. Relator: Min. Mauro Campbell Marques. DJe 31/05/2013; STJ (2. Turma). REsp 1676138/RJ. Relator: Min. Herman Benjamin. Julgado em: 05/09/2017. DJe 09/10/2017.
} 
Revista Eletrônica de Direito Processual - REDP.

Rio de Janeiro. Ano 15. Volume 22. Número 2. Maio a Agosto de 2021

Periódico Quadrimestral da Pós-Graduação Stricto Sensu em Direito Processual da UERJ

Patrono: José Carlos Barbosa Moreira (in mem.). ISSN 1982-7636. pp. 619-647

www.redp.uerj.br

mas, em contrapartida, não dependem de prévia garantia de juízo, somente exigível quando o devedor requer a outorga desse efeito.

Garantia do juízo da execução e efeito suspensivo dos embargos devem ser compreendidos dentro do contexto geral e sistemático do instituto dos embargos à execução que, como se verá adiante, jamais decorreu das peculiaridades da relação entre o contribuinte e a Fazenda Pública, mas resultou da mera repetição da regra já prevista no regramento instituído pelo CPC de 1973.

\section{TRÊS RAZÕES PARA DEFENDER A APLICAÇÃO DAS REGRAS DO CPC À DISPENSA DA GARANTIA DO JUÍZO NOS EMBARGOS À EXECUÇÃo FISCAL}

\subsection{INAPLICABILIDADE DO PRINCÍPIO DA ESPECIALIDADE}

A defesa na execução fiscal instituída pela Lei n. ${ }^{\circ}$ 6.830/1980 não decorreu das peculiaridades da relação entre o contribuinte e a Fazenda Pública, mas resultou da mera repetição da regra já prevista no regramento instituído pelo CPC de 1973. O princípio da especialidade não incide, como se demonstrará, no procedimento de defesa à execução fiscal, pois não se trata da criação de um procedimento específico para atender as especificidades da relação material entre o fisco e o contribuinte.

Em um escorço histórico, $\mathrm{Cunha}^{9}$ demonstra que a exigência de garantia do juízo estabelecida pelo artigo $16, \S 1 .^{\circ}$, da LEF deveu-se ao fato de o CPC de 1973 trazer essa exigência, e não à necessidade de um procedimento de defesa à execução específico para a Fazenda Pública.

O CPC de 1939 previa um sistema binário, a execução ocorria de duas formas: havia a ação executiva (arts. 298 a 301), que tratava da execução de títulos executivos extrajudiciais, e a denominada por Liebman "ação executória" (art. 882 et seq.), que era reservada à execução de sentença.

Com o advento do CPC de 1973, na sua primeira versão, esse sistema dual foi abolido. O CPC de 1973, contrariamente ao CPC de 1939, em sua estrutura originária,

\footnotetext{
${ }^{9}$ CUNHA, Leonardo Carneiro da. A Fazenda Pública em juízo. 11. ed. São Paulo: Dialética, 2013, p. 455.
} 
Revista Eletrônica de Direito Processual - REDP.

Rio de Janeiro. Ano 15. Volume 22. Número 2. Maio a Agosto de 2021

Periódico Quadrimestral da Pós-Graduação Stricto Sensu em Direito Processual da UERJ

Patrono: José Carlos Barbosa Moreira (in mem.). ISSN 1982-7636. pp. 619-647

www.redp.uerj.br

unificou as execuções, submetendo-as ao mesmo procedimento, tanto a execução fundada em título executivo judicial como a fundada em título executivo extrajudicial. Independentemente de estar fundada em título judicial ou extrajudicial, a execução submetia-se ao mesmo procedimento: o executado era citado para, em 24 horas, pagar ou nomear bens à penhora. A esse procedimento também se submetia a execução físcal ${ }^{10}$.

Desse modo, em todas as execuções (título judicial, extrajudicial e também a execução fiscal), a defesa fazia-se por meio dos embargos, que dependiam da garantia do juízo.

No entanto, em 1980, com o advento da Lei n. ${ }^{\circ}$ 6.830, que passou a dispor sobre a execução fiscal, essa unidade foi desfeita. O propósito da referida lei foi estabelecer uma disciplina própria para a cobrança da dívida ativa, dando-lhe garantias e benefícios não presentes na execução civil, regulada no CPC, instituindo-lhe, assim, um regime específico. Contudo, não houve nenhuma inovação no que se refere à forma de defesa na execução fiscal. A exigência da prévia garantia do juízo para a oposição dos embargos à execução - feita no parágrafo $1 .^{\circ}$ do artigo 16 da Lei n. ${ }^{\circ}$ 6.830/1980 - não decorre de detalhes, vicissitudes ou particularidades na relação entre o contribuinte e a Fazenda Pública $^{11}$.

Com efeito, quando foi editada a Lei n. ${ }^{\circ}$ 6.830/1980, foi mantido o mesmo procedimento de defesa - exigência da garantia do juízo para a oposição dos embargos -, que era a regra geral aplicável a qualquer execução e que, obviamente, nunca decorreu das particularidades da relação entre o fisco e o contribuinte, sendo apenas repetida a regra já prevista no CPC.

A Lei n. ${ }^{\circ}$ 11.382/2006 modificou a estrutura dos embargos à execução, retirandolhe o efeito suspensivo automático, como regra (art. 739-A do CPC/1973), bem como a exigência da prévia garantia de juízo (art. 736 do CPC/1973). A opção do legislador pela nova sistemática de defesa na execução não é uma peculiaridade da execução regulada no CPC, mas deve ser compreendida dentro do contexto geral e sistemático do instituto dos embargos à execução aplicável também à execução fiscal, uma vez que a exigência da

\footnotetext{
${ }^{10}$ CUNHA, Leonardo Carneiro da. A Fazenda Pública em juízo. 11. ed. São Paulo: Dialética, 2013, p. 455.

${ }^{11}$ CUNHA, Leonardo Carneiro da. A Fazenda Pública em juízo. 11. ed. São Paulo: Dialética, 2013, p. 455.
} 
Revista Eletrônica de Direito Processual - REDP.

Rio de Janeiro. Ano 15. Volume 22. Número 2. Maio a Agosto de 2021

Periódico Quadrimestral da Pós-Graduação Stricto Sensu em Direito Processual da UERJ

Patrono: José Carlos Barbosa Moreira (in mem.). ISSN 1982-7636. pp. 619-647

www.redp.uerj.br

prévia garantia do juízo para a oposição dos embargos na execução fiscal nunca decorreu das particularidades da relação entre fisco e o contribuinte, não havendo uma especificidade que justifique sua manutenção após as inovações legislativas para dispensar a garantia do juízo para a oposição de embargos.

\subsection{A CARGA VALORATIVA DAS NORMAS CONSTITUCIONAIS TRAZIDAS PELO CPC DE 2015: O FENÔMENO DO NEOCONSTITUCIONALISMO E DO NEOPROCESSUALISMO}

Após a Segunda Grande Guerra, passou-se a refletir no Ocidente sobre a necessidade de se consagrarem direitos inerentes à dignidade humana de maneira firme e duradoura para proteger os indivíduos contra os abusos que pudessem ser cometidos pelos Estados, mediante a criação de mecanismos efetivos de controle da Constituição Federal (CF).

Desse modo, desde o pós-guerra, o mundo começou a viver o fenômeno da constitucionalização do direito ${ }^{12}$, tendo início um novo marco teórico chamado "neoconstitucionalismo"13, com a mudança de paradigmas, como o reconhecimento da força normativa da Constituição ${ }^{14}$, a expansão da jurisdição constitucional e o giro linguístico rumo à teoria discursiva do direito ${ }^{15}$.

Essa mudança de paradigma, alterando o Estado de Direito para o Estado Democrático de Direito ${ }^{16}$, causou a construção de uma nova realidade constitucional em que a tutela dos direitos fundamentais passou a ser vista como a base de qualquer Estado ${ }^{17}$.

\footnotetext{
12 Sobre neoconstitucionalismo, cf.: BUENO, Cassio Scarpinella. O "modelo constitucional do direito processual civil": um paradigma necessário de estudo do direito processual civil e algumas de suas aplicações. Revista de Processo, São Paulo, v. 33, n. 161, jul. 2008, p. 268; CARBONELL, Miguel. Neoconstitucionalismo. Madrid: Trotta, 2009, p. 49-58; MITIDIERO, Daniel. Colaboração no processo civil: pressupostos sociais, lógicos e éticos. São Paulo: Revista dos Tribunais, 2009, p. 32-62.

13 Atribui-se o termo a Susanna Pozzolo (Neoconstitucionalismo y especificidad de la interpretación constitucional. Doxa: Cuadernos de Filosofía del Derecho, Buenos Aires, n. 21, p. 339-353, 1998. Disponível em: http://www.cervantesvirtual.com/obra/n-21---1998/. Acesso em: 10 abr. 2017).

${ }^{14}$ HESSE, Konrad. A força normativa da constituição. Porto Alegre: Safe, 1991, p. 54.

${ }^{15}$ BARROSO, Luís Roberto. O direito constitucional e a efetividade de suas normas: limites e possibilidades da Constituição brasileira. 9. ed. Rio de Janeiro: Renovar, 2009b, p. 358.

${ }^{16}$ CANOTILHO, José Joaquim Gomes. Direito constitucional e teoria da constituição. 6. ed. Coimbra: Almedina, 2003, p. 78.

${ }^{17}$ Esse fenômeno evidentemente não aconteceu simultaneamente em todos os países. A Itália (Constituição de 1947) e a Alemanha (Lei Fundamental de Bonn, de 1949), por exemplo, viveram essa fase desde o período do pós-Segunda Guerra, mas o nosso país, tal qual Espanha (Constituição de 1978) e Portugal
} 
Revista Eletrônica de Direito Processual - REDP.

Rio de Janeiro. Ano 15. Volume 22. Número 2. Maio a Agosto de 2021

Periódico Quadrimestral da Pós-Graduação Stricto Sensu em Direito Processual da UERJ

Patrono: José Carlos Barbosa Moreira (in mem.). ISSN 1982-7636. pp. 619-647

www.redp.uerj.br

Segundo Acosta Sánchez ${ }^{18}$, os direitos fundamentais converteram-se em base de legitimidade e de validade, junto à soberania popular, dos poderes públicos e do direito, produzindo efeitos irradiantes em todos os terrenos do ordenamento jurídico.

Com o reconhecimento da força normativa da Constituição, suas normas passam a ter eficácia vinculativa e positividade, deixando de serem simples normas programáticas, isto é, simples declarações políticas ou exortações morais. Assumindo um caráter imperativo, as normas constitucionais vão regular as condutas, vinculando todos seus órgãos concretizadores (Legislativo, Executivo e Judiciário).

A efetividade da Constituição encontra no processo o meio de concretude dos direitos nela reconhecidos, o que acaba por provocar uma mudança na estrutura do processo, pois não é mais possível compreendê-lo sem, antes, buscar seus fundamentos na Constituição.

A esse fenômeno que provoca um redimensionamento no processo convencionouse chamar "neoprocessualismo", porque, tal qual se deu na Constituição, também houve uma mudança de paradigma na forma de interpretar o processo, que não pode mais ser dissociado da Lei fundamental.

A evolução do constitucionalismo foi decisiva para as mudanças estruturais do estudo e do dimensionamento da ciência processual. Começou-se a perceber que o processo não é algo destituído de conotações éticas e deontológicas, mas tem objetivos metajurídicos, escopos sociais e políticos que transcendem a mera técnica processual.

"Neoprocessualismo"19 é um termo que visa designar uma nova concepção de processo baseada no reconhecimento da força normativa da Constituição e resultante da constitucionalização dos direitos e garantias processuais ${ }^{20}$. Com efeito, na atualidade, não é

(Constituição de 1976), somente iria passar por tal fenômeno mais tardiamente (BARROSO, Luís Roberto. Curso de Direito Constitucional Contemporâneo. São Paulo: Saraiva, 2009a, p. 362).

18 ACOSTA SÁNCHEZ, José. Formación de la Constitución y jurisdicción constitucional: fundamentos de la democracia constitucional. Madrid: Tecnos, 1998, p. 177-178.

${ }^{19}$ Para alguns, o formalismo valorativo é apontado como um neoprocessualismo com o reforço da ética e da boa-fé no processo. Cf.: DIDIER JR., Fredie. Curso de Direito Processual Civil: introdução ao direito processual civil, parte geral e processo de conhecimento. 19. ed. Salvador: JusPodivm, 2017, p. 50 et seq.

20 CAMBI, Eduardo. Neoconstitucionalismo e neoprocessualismo. Revista do Programa de PósGraduação em Direito da Universidade Federal da Bahia, Salvador, v. 2, n. 17, 2008, p. 98. Homenagem ao Professor Luiz de Pinho Pedreira. Disponível em: 
Revista Eletrônica de Direito Processual - REDP.

Rio de Janeiro. Ano 15. Volume 22. Número 2. Maio a Agosto de 2021

Periódico Quadrimestral da Pós-Graduação Stricto Sensu em Direito Processual da UERJ

Patrono: José Carlos Barbosa Moreira (in mem.). ISSN 1982-7636. pp. 619-647

www.redp.uerj.br

mais possível compreender o processo sem, antes, buscar seus fundamentos na Constituição.

Assim, se antes as leis e os códigos colocavam-se no centro do sistema jurídico, agora a Constituição é a base para a interpretação e a argumentação jurídicas.

Foi assim que se constitucionalizou o processo, o que significa dizer que as garantias $^{21}$ do processo passaram a ser previstas entre os direitos fundamentais no Estado Democrático de Direito, exigindo um novo paradigma de processo que se coadune com os parâmetros éticos e morais aceitáveis pelo consenso dos homens livres de qualquer época ou lugar, enquanto se revele capaz de realizar uma justiça verdadeiramente imparcial, fundada na natureza e na razão ${ }^{22}$.

Nessa toada, o CPC de 2015 traz consigo toda a carga valorativa das normas constitucionais, apresentando no seu Capítulo I as normas fundamentais do processo civil $^{23}$. Mas, como visto acima, a constitucionalização do direito não é inerente apenas ao direito processual, as premissas metodológicas e valorativas previstas constitucionalmente espraiam-se por todo o ordenamento jurídico, inclusive na aplicação das normas infraconstitucionais anteriores à Constituição ${ }^{24}$.

https://vitorfreitas.goias.ufg.br/up/662/o/Eduardo_Cambi_Neoconstitucionalismo_e_Neoprocessualismo.pdf. Acesso em: 2 jan. 2020.

${ }^{21}$ Para Comoglio, garantia, em sentido genérico, exprime a diferença entre um direito reconhecido, ou atribuído em abstrato pelas normas, e um direito realmente protegido, ou atuável em concreto. Diz assim o autor: "In generale, si intende per 'garanzia' ogni strumento o presidio tecnico-giuridico, il quale sia in grado di far convertire un diritto puramente 'riconosciuto', o attribuito' in astratto dalle norme, in un diritto effettivamente protetto in concreto, e quindi suscettibile di piena 'attuazione' o 'reintegrazione' ogni qual volta risulti violato" (COMOGLIO, Luigi Paolo. Garanzie costituzionali e "giusto processo": modelli a confronto. Revista de Processo, São Paulo, v. 23, n. 90, abr./jun. 1998, p. 100). Sinteticamente, Paulo Bonavides explica que "garantia é a posição que afirma a segurança e põe cobro à incerteza e à fragilidade" (BONAVIDES, Paulo. Curso de Direito Constitucional. São Paulo: Malheiros, 2006, p. 481).

${ }^{22}$ COMOGLIO, Luigi Paolo. Garanzie costituzionali e "giusto processo": modelli a confronto. Revista de Processo, São Paulo, v. 23, n. 90, abr./jun. 1998, p. 105.

${ }^{23}$ SILVA, Luiz Octavio Pinheiro Carvalho da; SCIOLLA, Daniella de Jesus Silva. Execução fiscal e novo Código de Processo Civil: haverá um processo realmente justo? In: DUARTE, Fernanda; BOMFIM, Gilson; MURAYAMA, Janssen (org.). A LEF e o Novo CPC: reflexões e tendências, o que ficou e o que mudará. Rio de Janeiro: Lumen Juris, 2016, p. 10.

${ }^{24}$ SILVA, Luiz Octavio Pinheiro Carvalho da; SCIOLLA, Daniella de Jesus Silva. Execução fiscal e novo Código de Processo Civil: haverá um processo realmente justo? In: DUARTE, Fernanda; BOMFIM, Gilson; MURAYAMA, Janssen (org.). A LEF e o Novo CPC: reflexões e tendências, o que ficou e o que mudará. Rio de Janeiro: Lumen Juris, 2016, p. 10. 
Revista Eletrônica de Direito Processual - REDP.

Rio de Janeiro. Ano 15. Volume 22. Número 2. Maio a Agosto de 2021

Periódico Quadrimestral da Pós-Graduação Stricto Sensu em Direito Processual da UERJ

Patrono: José Carlos Barbosa Moreira (in mem.). ISSN 1982-7636. pp. 619-647

www.redp.uerj.br

Assim, embora a Lei de Execução Fiscal (Lei n. ${ }^{\circ}$ 6.830/1980) ${ }^{25}$ tenha sido recepcionada, há um evidente descompasso metodológico e principiológico em relação à Constituição Federal de 1988, não se podendo, sob o manto de que foi editada em momento anterior à Constituição, ignorar que sobre ela incide o fenômeno do neoprocessualismo, o qual traz uma nova concepção de processo baseado no reconhecimento da força normativa da Constituição e resulta da constitucionalização dos direitos e garantias processuais.

Logo, embora o STJ tenha invocado o princípio da especialidade da LEF para manter a garantia como condicionante dos embargos, não se pode desprezar, por certo, a carga valorativa das normas constitucionais trazidas pelo Código atual. O fundamento no qual se firmou a decisão do STJ - "lei especial derroga lei geral" - deve ser analisado sob as novas premissas que resultam da constitucionalização dos direitos e garantias processuais, pois não há simplesmente um conflito normativo, há também um conflito principiológico, colocando frente a frente dois modelos de processo nitidamente distintos. Deve-se então arguir qual deles é mais adequado a atender o devido processo legal, previsto constitucionalmente ${ }^{26}$.

Observou Faria ${ }^{27}$ que, nesse contexto de sucessão de leis no tempo, surgiram certas perplexidades hermenêuticas acerca da legislação aplicável ao processo de execução fiscal. Com efeito, os elementos clássicos de interpretação e os critérios tradicionais de solução de conflitos não são capazes de lidar com essa incoerência, porque as soluções interpretativas são incompatíveis com o novo paradigma jurídico-filosófico adotado a partir da

\footnotetext{
${ }^{25}$ E também o Código Tributário Nacional (CTN), Lei n. ${ }^{\circ}$ 5.172, de 25 de outubro de 1966.

${ }^{26}$ SANTIAGO, Julio Cesar. A influência do Novo CPC na cobrança judicial do crédito tributário. In: DUARTE, Fernanda; BOMFIM, Gilson; MURAYAMA, Janssen. A LEF e o Novo CPC: Reflexões e tendências, o que ficou e o que mudará. Rio de Janeiro: Lumen Juris, 2016, p. 26. Nesse mesmo sentido, Lorenzoni e Rocha: "Não obstante, devemos recordar que a LEF foi promulgada na época em que o país vivia um período de exceção através do Regime da Ditadura Militar. Então, a despeito da lei ter sido recepcionada pelo novo ordenamento constitucional de 1988, fato é que o NCPC se adequa melhor aos anseios do constituinte originário e derivado" (LORENZONI, Brunno; ROCHA, Sergio André. O incidente de desconsideração da personalidade jurídica e sua aplicação no processo de execução fiscal. In: DUARTE, Fernanda; BOMFIM, Gilson; MURAYAMA, Janssen (org.). A LEF e o Novo CPC: reflexões e tendências, o que ficou e o que mudará. Rio de Janeiro: Lumen Juris, 2016, p. 215.

${ }^{27}$ FARIA, Marcio Gustavo Senra. Interações entre o Novo CPC e a LEF: a Teoria do Diálogo das Fontes no processo de execução fiscal. In: DUARTE, Fernanda; BOMFIM, Gilson; MURAYAMA, Janssen (org.). A LEF e o Novo CPC: reflexões e tendências, o que ficou e o que mudará. Rio de Janeiro: Lumen Juris, 2016, p. 54-61.
} 
Revista Eletrônica de Direito Processual - REDP.

Rio de Janeiro. Ano 15. Volume 22. Número 2. Maio a Agosto de 2021

Periódico Quadrimestral da Pós-Graduação Stricto Sensu em Direito Processual da UERJ

Patrono: José Carlos Barbosa Moreira (in mem.). ISSN 1982-7636. pp. 619-647

www.redp.uerj.br

Constituição de 1988, devendo-se admitir a moderna Teoria do Diálogo das Fontes como mediadora das interações entre o CPC e a LEF para o processo de execução fiscal.

Logo, a antinomia entre o artigo 16, $\S 1 .^{\circ}$, da LEF (que exige a garantia do juízo para o manejo dos embargos à execução) e o artigo 914 do CPC/2015 (que dispensa a garantia do juízo como condicionante dos embargos) deve ser superada com a aplicação da Teoria do Diálogo das Fontes, idealizada pelo alemão Erik Jayme e aplicada, no Brasil, pela primeira vez, por Claudia Lima Marques, a fim de preservar a coexistência entre o Código de Defesa do Consumidor e o novo Código Civil ${ }^{28}$.

O diálogo das fontes é o meio hábil para a solução de problemas da antinomia que resulta da incoerência entre regras jurídicas, de tal forma que os princípios conferem unidade axiológica ao sistema jurídico, funcionando como guias para orientar o intérprete na solução de antinomias ${ }^{29}$. Antonio Herman Benjamin e Claudia Lima Marques sustentam que a teoria do diálogo das fontes busca promover plasticidade, de tal forma que o diálogo é contra a rigidez do monólogo, típico do discurso metodológico rígido tradicional ${ }^{30}$.

Em síntese, portanto, a teoria prega a superação da noção de conflito de leis pela ideia de coordenação de leis, à luz dos valores e direitos fundamentais consagrados na Constituição e dos Direitos Humanos. As leis que tenham campos de aplicação diferentes, mas convergentes, convivem de forma harmônica num mesmo sistema jurídico interagindo entre si com as diferentes possibilidades de diálogo para que alcancem, assim, suas finalidades ${ }^{31}$.

\footnotetext{
${ }^{28}$ FARIA, Marcio Gustavo Senra. Interações entre o Novo CPC e a LEF: a Teoria do Diálogo das Fontes no processo de execução fiscal. In: DUARTE, Fernanda; BOMFIM, Gilson; MURAYAMA, Janssen (org.). $A$ $L E F$ e o Novo CPC: reflexões e tendências, o que ficou e o que mudará. Rio de Janeiro: Lumen Juris, 2016, p. 61.

${ }^{29}$ LEAL, Pastora do Socorro Teixeira. "Diálogo" das fontes e responsabilidade civil: um aporte para a formulação do conceito de dano de conduta. In: LOURENÇO, Cristina Silvia Alves; BARBALHO, Lucas de Siqueira Mendes; RODRIGUES, Victor Russo Fróes; NÓVOA, Victor Siqueira Mendes de (org.). Estudos de Ciências Criminais e Filosofia do Direito: Homenagem ao Emérito Professor Ney Siqueira Mendes. Rio de Janeiro: Lumen Juris, 2019, p. 247.

30 "Plasticidade, pois diálogo é contra a rigidez do 'monólogo', é contra o discurso metodológico rígido tradicional (de um método superando outro, de uma lei revogando a outra, de outra fonte ou valor ser superior ao outro)" (BENJAMIN, Antonio Herman; MARQUES, Claudia Lima. A teoria do diálogo das fontes e seu impacto no Brasil: uma homenagem a Erik Jayme. Revista de Direito do Consumidor, São Paulo, v. 27, n. 115, jan./fev. 2018, p. 23).

${ }^{31}$ FARIA, Marcio Gustavo Senra. Interações entre o Novo CPC e a LEF: a Teoria do Diálogo das Fontes no processo de execução fiscal. In: DUARTE, Fernanda; BOMFIM, Gilson; MURAYAMA, Janssen (org.). A
} 
Revista Eletrônica de Direito Processual - REDP.

Rio de Janeiro. Ano 15. Volume 22. Número 2. Maio a Agosto de 2021

Periódico Quadrimestral da Pós-Graduação Stricto Sensu em Direito Processual da UERJ

Patrono: José Carlos Barbosa Moreira (in mem.). ISSN 1982-7636. pp. 619-647

www.redp.uerj.br

Portanto, a necessidade de interpretação do processo de execução fiscal à luz das normas fundamentais trazidas pelo CPC é uma expressão da teoria do diálogo das fontes, podendo-se daí extrair o entendimento de que a dispensa da garantia do juízo como condicionante dos embargos, prevista no artigo 914 do CPC/2015, por ser norma genérica mais consentânea aos valores constitucionais, prefere à norma especial do artigo 16, § 1. , da LEF, que exige a garantia do juízo para o manejo dos embargos à execução.

Com efeito, não se pode negar a concretização dos valores positivados na Constituição no procedimento que move a execução ${ }^{32}$. É incoerente que, em um Estado Democrático de Direito, a execução fiscal exija a garantia como condicionante dos embargos, desprezando os princípios de acesso à justiça e de direito de defesa, positivados na Constituição Federal.

Há de se aplicar, portanto, à LEF a carga valorativa das normas constitucionais trazidas pelo CPC de 2015, especificamente em relação aos embargos à execução fiscal, considerando que a exigência da prévia garantia do juízo para a oposição desses embargos não se coaduna com os princípios constitucionais de acesso à justiça e do devido processo legal previstos entre os direitos fundamentais no Estado Democrático de Direito.

\subsection{A SÚMULA VINCULANTE 28 DO STF: DEVEM-SE APLICAR AOS EMBARGOS À EXECUÇÃO FISCAL AS MESMAS CONSEQUÊNCIAS JURÍDICAS DA AÇÃO ANULATÓRIA}

O posicionamento consolidado pelo STJ no julgamento do REsp 1272827/PE ${ }^{33}$, analisado sob a sistemática dos recursos repetitivos, admitindo que os embargos à execução fiscal somente podem ser manejados após a garantia do juízo, não apenas viola a

LEF e o Novo CPC: reflexões e tendências, o que ficou e o que mudará. Rio de Janeiro: Lumen Juris, 2016, p. 60.

${ }^{32}$ SILVA, Luiz Octavio Pinheiro Carvalho da; SCIOLLA, Daniella de Jesus Silva. Execução fiscal e novo Código de Processo Civil: haverá um processo realmente justo? In: DUARTE, Fernanda; BOMFIM, Gilson; MURAYAMA, Janssen (org.). A LEF e o Novo CPC: reflexões e tendências, o que ficou e o que mudará. Rio de Janeiro: Lumen Juris, 2016, p. 11.

33 “[...] Em atenção ao princípio da especialidade da LEF, mantido com a reforma do CPC/73, a nova redação do art. 736, do CPC dada pela Lei n. 11.382/2006 - artigo que dispensa a garantia como condicionante dos embargos - não se aplica às execuções fiscais diante da presença de dispositivo específico, qual seja o art. 16, $\S 1^{\circ}$, da Lei n. 6.830/80, que exige expressamente a garantia para a apresentação dos embargos à execução fiscal [...]" (STJ (1. Seção). REsp 1.272.827/PE. Relator: Min. Mauro Campbell Marques. Julgado em: 22/05/2013. DJe 31/05/2013). 
Revista Eletrônica de Direito Processual - REDP.

Rio de Janeiro. Ano 15. Volume 22. Número 2. Maio a Agosto de 2021

Periódico Quadrimestral da Pós-Graduação Stricto Sensu em Direito Processual da UERJ

Patrono: José Carlos Barbosa Moreira (in mem.). ISSN 1982-7636. pp. 619-647

www.redp.uerj.br

garantia do direito de defesa e o princípio constitucional de acesso à justiça, mas, principalmente, é incongruente com o posicionamento assentado pelo STF, que já decidiu (Súmula Vinculante 28) pela inconstitucionalidade da exigência do depósito prévio como requisito de admissibilidade de ação judicial na qual se pretenda discutir a exigibilidade do crédito tributário.

Embora a Súmula Vinculante 28 do STF trate especificamente da ação anulatória e não dos embargos, a ação anulatória constitui defesa heterotópica, isto é, defesa fora do tópico, do lugar comum, que veicula o mesmo conteúdo dos embargos. Trata-se, essencialmente, de embargos ajuizados em outra oportunidade, devendo ser aplicado o mesmo tratamento jurídico a ambos.

Explicamos.

A Súmula Vinculante 28 do STF estabelece: "é inconstitucional a exigência de depósito prévio como requisito de admissibilidade de ação judicial na qual se pretenda discutir a exigibilidade de crédito tributário".

A possibilidade de ajuizamento de ação autônoma para discutir o débito constante no título vem do texto original do CPC de 1973 que, em seu artigo 585, § 1. , trazia: "a propositura da ação anulatória de débito fiscal não inibe a Fazenda de promover-lhe a cobrança". Revogado o texto pela Lei n. ${ }^{\circ} 8.953 / 1994$, a nova redação dada ao referido dispositivo ampliou as hipóteses para além da Fazenda Pública, ao dispor: "a propositura de qualquer ação relativa ao débito constante do título executivo não inibe o credor de promover-lhe a execução". Essa mesma redação foi mantida pelo CPC de 2015 em seu artigo $784, \S 11^{\circ}$.

O dispositivo modificado do CPC de 1973 destinava-se unicamente à Fazenda Pública e referia-se somente à propositura da ação anulatória do débito fiscal, reforçando o estatuído no Decreto-Lei n. ${ }^{\circ}$ 147/1967, o qual determinara que a Fazenda Pública promovesse a inscrição e a execução da dívida se a ação anulatória respectiva não houvesse sido precedida de depósito (art. 20, § 1. $\left.{ }^{\circ}\right)^{34} 35$.

34 BELTRAME, José Alonso. Dos embargos do devedor. 2. ed. São Paulo: Saraiva, 1983, p. 134; BERMUDES, Sergio. A reforma do Código de Processo Civil. 2. ed. São Paulo, Saraiva, 1996, p. 132; NERY JUNIOR, Nelson; NERY, Rosa Maria de Andrade. Código de Processo Civil comentado. 16. ed. São 
Revista Eletrônica de Direito Processual - REDP.

Rio de Janeiro. Ano 15. Volume 22. Número 2. Maio a Agosto de 2021

Periódico Quadrimestral da Pós-Graduação Stricto Sensu em Direito Processual da UERJ

Patrono: José Carlos Barbosa Moreira (in mem.). ISSN 1982-7636. pp. 619-647

www.redp.uerj.br

Vale lembrar que a obrigatoriedade do depósito para a propositura da ação anulatória de débito fiscal foi prevista no artigo 38 da Lei n. ${ }^{\circ} 6.830 / 1980^{36}$, contudo, a literalidade do entendimento constante no referido dispositivo sempre foi afastada pela doutrina $^{37}$, sob o argumento de que o referido dispositivo deveria ser interpretado em conformidade com o artigo 151, II, do CTN, defendendo-se que o depósito preparatório somente poderia ser exigível se o autor da ação anulatória de débito fiscal também tivesse por objetivo obstar sua cobrança judicial pela Fazenda Pública ${ }^{38}$. Esse posicionamento também se foi consolidando na jurisprudência do STF, anterior à Constituição de 1988, que se firmou no mesmo sentido: o depósito previsto no artigo 38 da Lei n. ${ }^{\circ}$ 6.830/1980 somente deve ser obrigatório se o sujeito passivo pretender inibir a Fazenda Pública de propor a execução fiscal ${ }^{39}$. Sobre o assunto, o extinto Tribunal Federal de Recursos editou o Enunciado n. ${ }^{\circ}$ 247: "Não constitui pressuposto da ação anulatória do débito fiscal o depósito de que cuida o art. 38 da Lei 6830, de 1980”.

Paulo: Revista dos Tribunais, 2016, p. 1759; SHIMURA, Sergio Seiji. Título executivo. 2. ed. São Paulo: Método, 2005, p. 344.

${ }^{35}$ Com a redação do $\S 1 .^{\circ}$ do artigo 585 do CPC/1973, ampliado pela Lei n. ${ }^{\circ} 8.953 / 1994$, a doutrina passou a dar uma interpretação extensiva; por uma questão de isonomia processual, passou-se a admitir a propositura de defesa heterotópica em relação aos demais títulos executivos extrajudiciais.

${ }^{36}$ Artigo 38 da Lei n. ${ }^{\circ}$ 6.830/1980: "a discussão judicial da Dívida Ativa da Fazenda Pública só é admissível em execução, na forma desta Lei, salvo as hipóteses de mandado de segurança, ação de repetição de indébito ou ação anulatória do ato declarativo da dívida, esta precedida de depósito preparatório do valor do débito, monetariamente corrigido e acrescido dos juros e multa de mora e demais encargos".

${ }^{37}$ MACHADO, Hugo de Brito. Execução fiscal e ação anulatória. Revista de Processo, São Paulo, v. 6, n. 24, out./dez. 1981, p. 116.

${ }^{38}$ PACHECO, José da Silva. Comentários à nova Lei de Execução Fiscal. São Paulo: Saraiva, 1981, p. 278-283; SZKLAROWSKY, Leon Frejda. Execução fiscal. Brasília, DF: Ministério da Fazenda, 1984, p. 31-40. Em edição atual: THEODORO JÚNIOR, Humberto. Execução fiscal. 13. ed. São Paulo: Saraiva, 2016, p. 699.

39 “Ação anulatória de débito fiscal. Art. 38 da lei 6.830/80. Razoável é a interpretação do Aresto recorrido no sentido de que não constitui requisito para a propositura da ação anulatória de débito fiscal o depósito previsto no referido artigo. Tal obrigatoriedade ocorre se o sujeito passivo pretender inibir a Fazenda Pública de propor a execução fiscal. Recurso extraordinário não conhecido" (STF (2. Turma). RE 105552. Relator: Min. Djaci Falcão. Julgado em: 02/08/1985. DJ 30/08/1985, PP-14351); "Ação anulatória de débito fiscal. Depósito prévio. Art. 38 da Lei de Execuções Fiscais (Lei 6830/80). Pressuposto da ação anulatória de ato declaratório da dívida ativa e o lançamento do crédito tributário, não havendo sentido em protraí-lo ao ato de inscrição da dívida. O depósito preparatório do valor do débito não é condição de procedibilidade da ação anulatória, apenas, na circunstância, não é impeditiva da execução fiscal, que com aquela não produz litispendência, embora haja conexidade. Entretanto, a satisfação do ônus do depósito prévio da ação anulatória, por ter efeito de suspender a exigibilidade do crédito (art-151, II, do CTN), desautoriza a instauração da execução fiscal. Recurso extraordinário não conhecido" (STF (1. Turma). RE 103400. Relator: Min. Rafael Mayer. Julgado em: 10/12/1984. DJ 01/02/1985, PP-10474). 
Revista Eletrônica de Direito Processual - REDP.

Rio de Janeiro. Ano 15. Volume 22. Número 2. Maio a Agosto de 2021

Periódico Quadrimestral da Pós-Graduação Stricto Sensu em Direito Processual da UERJ

Patrono: José Carlos Barbosa Moreira (in mem.). ISSN 1982-7636. pp. 619-647

www.redp.uerj.br

Referido posicionamento embasava-se no fato de que a admissão da

imprescindibilidade do depósito para a propositura da ação anulatória seria "ferir a garantia do artigo 153, § 4. ${ }^{\circ}$, da CF/1967”: “a lei não poderá excluir da apreciação do Poder Judiciário qualquer lesão de direito individual"40. Esse também foi o embasamento sustentado pelo STJ, agora sob a égide da Constituição Federal de 1988, analisando a questão sob a sistemática dos repetitivos:

\begin{abstract}
A propositura de ação anulatória de débito fiscal não está condicionada à realização do depósito prévio previsto no art. 38 da Lei de Execuções Fiscais, posto não ter sido o referido dispositivo legal recepcionado pela Constituição Federal de 1988, em virtude de incompatibilidade material com o art. $5 .^{\circ}$, inciso XXXV, verbis: 'a lei não excluirá da apreciação do Poder Judiciário lesão ou ameaça a direito ${ }^{41}$.
\end{abstract}

Tal matéria, portanto, que não é nova, mereceu um posicionamento do STF, que

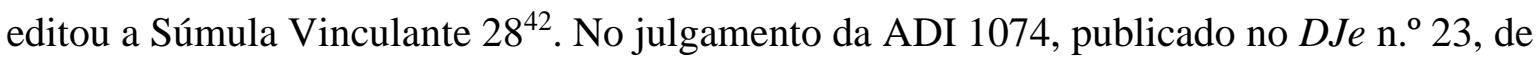
25 de maio de 2007, precedente que levou à edição da referida súmula vinculante, o

40 TFR (4. Turma). ApC. 52.748-SP. Relator: Min. Antônio de Pádua Ribeiro. Julgado em: 17/03/1982. Revista do Tribunal Federal de Recursos, n. 105, p. 59-62, jan. 1984.

41 "PROCESSUAL CIVIL E TRIBUTÁRIO. RECURSO ESPECIAL REPRESENTATIVO DE CONTROVÉRSIA. ART. 543-C DO CPC. AJUIZAMENTO DE AÇÃO ANULATÓRIA DO CRÉDITO FISCAL. CONDICIONAMENTO AO DEPÓSITO PRÉVIO DO MONTANTE INTEGRAL. IMPOSSIBILIDADE. VIOLAÇÃO DO ART. 535, II, DO CPC. INOCORRÊNCIA. 1. A propositura de ação anulatória de débito fiscal não está condicionada à realização do depósito prévio previsto no art. 38 da Lei de Execuções Fiscais, posto não ter sido o referido dispositivo legal recepcionado pela Constituição Federal de 1988, em virtude de incompatibilidade material com o art. $5^{\circ}$, inciso XXXV, verbis: 'a lei não excluirá da apreciação do Poder Judiciário lesão ou ameaça a direito'. 2. 'Ação anulatória de débito fiscal. art. 38 da lei 6.830/80. Razoável a interpretação do aresto recorrido no sentido de que não constitui requisito para a propositura da ação anulatória de débito fiscal o depósito previsto no referido artigo. Tal obrigatoriedade ocorre se o sujeito passivo pretender inibir a Fazenda Pública de propor a execução fiscal. Recurso extraordinário não conhecido.' (RE 105552, Relator Min. DJACI FALCAO, Segunda Turma, DJ 3008-1985) 3. Deveras, o depósito prévio previsto no art. 38, da LEF, não constitui condição de procedibilidade da ação anulatória, mas mera faculdade do autor, para o efeito de suspensão da exigibilidade do crédito tributário, nos termos do art. 151 do CTN, inibindo, dessa forma, o ajuizamento da ação executiva fiscal, consoante a jurisprudência pacífica do E. STJ. (Precedentes do STJ: AgRg nos EDcl no Ag 1107172/PR, Rel. Ministro HERMAN BENJAMIN, SEGUNDA TURMA, julgado em 03/09/2009, DJe 11/09/2009; REsp 183.969/SP, Rel. Ministro MILTON LUIZ PEREIRA, PRIMEIRA TURMA, julgado em 21/03/2000, DJ 22/05/2000; REsp 60.064/SP, Rel. Ministro DEMÓCRITO REINALDO, PRIMEIRA TURMA, julgado em 26/04/1995, DJ 15/05/1995; REsp 2.772/RJ, Rel. Ministro HUMBERTO GOMES DE BARROS, PRIMEIRA TURMA, julgado em 15/03/1995, DJ 24/04/1995). 4. O art. 535 do CPC resta incólume se o Tribunal de origem, embora sucintamente, pronuncia-se de forma clara e suficiente sobre a questão posta nos autos. Ademais, o magistrado não está obrigado a rebater, um a um, os argumentos trazidos pela parte, desde que os fundamentos utilizados tenham sido suficientes para embasar a decisão. 5. Recurso especial provido. Acórdão submetido ao regime do art. 543-C do CPC e da Resolução STJ 08/2008" (STJ (1. Seção). REsp 962.838/BA. Relator: Min. Luiz Fux. Julgado em: 25/11/2009. DJe 18/12/2009).

${ }^{42}$ A Súmula Vinculante 28 do STF foi aprovada em Sessão Plenária de 3 de fevereiro de 2010. 
Revista Eletrônica de Direito Processual - REDP.

Rio de Janeiro. Ano 15. Volume 22. Número 2. Maio a Agosto de 2021

Periódico Quadrimestral da Pós-Graduação Stricto Sensu em Direito Processual da UERJ

Patrono: José Carlos Barbosa Moreira (in mem.). ISSN 1982-7636. pp. 619-647

www.redp.uerj.br

Ministro Eros Grau ratifica o posicionamento já assentado, acentuando a inconstitucionalidade da obrigatoriedade do depósito para o ajuizamento de qualquer ação judicial que visasse discutir o débito, uma vez que prévio depósito como condição para a propositura de medida judicial representa cerceamento do acesso ao Poder Judiciário.

A decisão da Súmula Vinculante 28 considerou o depósito prévio inconstitucional porque representa cerceamento ao direito defesa condicionar a propositura da ação anulatória à sujeição a uma exigência que limita o acesso à justiça.

É exatamente nesse ponto que ocorre a incongruência entre o posicionamento do STJ - que exige a garantia para o processamento dos embargos à execução fiscal - e a Súmula Vinculante 28 do STF, porque a ação anulatória é defesa heterotópica, possuindo a mesma natureza e a mesma finalidade dos embargos à execução fiscal, segundo entendimento, inclusive, do próprio STJ, conforme se demonstrará.

A palavra "heterotópico", junção de "hetero" e "tópico", significa fora do tópico, em um lugar diferente. O termo "defesa heterotópica" enfatiza a sua "posição metodologicamente distinta das demais defesas utilizadas pelo executado" ${ }^{\prime 43}$. A defesa heterotópica é a defesa que está fora do lugar comum; expressa uma defesa manejada pelo executado fora do "tópico" próprio das defesas previstas pelo legislador. Logo, a ação anulatória é uma defesa heterotópica porque tem o mesmo conteúdo e a mesma finalidade da defesa típica, que são os embargos à execução físcal, previstos na Lei n. ${ }^{\circ}$ 6.830/1980; poderá ser ajuizada fora do momento ou da oportunidade desses embargos, sendo certo que seu resultado atingirá a própria execução, assim como ocorreria se os próprios embargos tivessem sido opostos.

Embora parte isolada da doutrina questione o cabimento das defesas heterotópicas sob o argumento de que permitir ao executado veicular o mesmo objeto litigioso da defesa típica - embargos - compromete a efetividade do processo, pois oferece mais um instrumento defensivo ao executado, violando o princípio da celeridade e admitindo uma

43 MIZRAHI, Gustavo José. O cabimento das chamadas defesas heterotópicas do executado. Revista Eletrônica de Direito Processual, Rio de Janeiro, v. 12, n. 12, 2013, p. 218. Disponível em: https://www.epublicacoes.uerj.br/index.php/redp/article/view/8679/6555. Acesso em: 30 out. 2014. 
Revista Eletrônica de Direito Processual - REDP.

Rio de Janeiro. Ano 15. Volume 22. Número 2. Maio a Agosto de 2021

Periódico Quadrimestral da Pós-Graduação Stricto Sensu em Direito Processual da UERJ

Patrono: José Carlos Barbosa Moreira (in mem.). ISSN 1982-7636. pp. 619-647

www.redp.uerj.br

nova forma de protelação ${ }^{44}$, tal posição não tem preponderado. A doutrina majoritária ${ }^{45}$

tem reconhecido que a defesa heterotópica não é apenas o mero exercício do direito de defesa, mas é garantia constitucional do direito de agir, prevista no artigo $5^{\circ}$, inciso $\mathrm{XXXV}$, da $\mathrm{CF}^{46}$. Trata-se de uma ação judicial, corolário da garantia constitucional do acesso à justiça ${ }^{47}$, indisponível e irrevogável ${ }^{48}$.

A ação anulatória não é apenas o mero exercício do direito de defesa manejado fora do momento procedimental legalmente previsto, mas é garantia constitucional do direito de agir. Por sua vez, os embargos, tendo sua natureza jurídica de ação reconhecida sem discrepância na doutrina ${ }^{49}$, não constituem o mero exercício do direito de defesa, mas

${ }^{44}$ RODRIGUES, Rafael de Oliveira. O abuso do processo por intermédio da defesa heterotópica. Revista Eletrônica de Direito Processual, Rio de Janeiro, v. 8, n. 8, 2011, p. 862. Disponível em: https://www.epublicacoes.uerj.br/index.php/redp/article/view/20846/15122. Acesso em: 30 out. 2012.

45 "O temor de que o instituto venha a ser mais um meio protelatório a obstaculizar a entrega da tutela jurisdicional não deve servir de fundamento a impedir o acesso de outrem à proteção da jurisdição" (MIZRAHI, Gustavo José. O cabimento das chamadas defesas heterotópicas do executado. Revista Eletrônica de Direito Processual, Rio de Janeiro, v. 12, n. 12, 2013, p. 226. Disponível em: https://www.epublicacoes.uerj.br/index.php/redp/article/view/8679/6555. Acesso em: 30 out. 2014).

46 "XXXV - a lei não excluirá da apreciação do Poder Judiciário lesão ou ameaça a direito".

47 NERY JUNIOR, Nelson. Princípios do processo na Constituição Federal: processo civil, penal e administrativo. 11. ed. São Paulo: Revista dos Tribunais, 2012. v. 1, p. 192. Vale ressaltar que essa questão foi intensamente debatida durante o Projeto do Novo Código de Processo Civil, o qual, na sua redação original, dispunha que "a ausência de embargos obsta à propositura de ação autônoma do devedor contra o credor para discutir o crédito" (PLS n..$^{\circ} 166$ de 2010, art. 839, $§ 2^{\circ}{ }^{\circ}$ ), inviabilizando, portanto, o manejo das defesas heterotópicas. O texto, suprimido na redação final, recebeu diversas críticas. Segundo Humberto Theodoro Júnior, o referido dispositivo trazia uma verdadeira barbaridade, atingindo as raias da inconstitucionalidade, em virtude da violação do direito de ação (direito de acesso à justiça) (THEODORO JÚNIOR, Humberto. Primeiras observações sobre o projeto do novo Código de Processo Civil. Revista Magister de Direito Civil e Processual Civil, Porto Alegre, v. 6, n. 36, p. 5-11, maio/jun. 2010. Disponível em: http://www.rkladvocacia.com/arquivos/artigos/art_srt_arquivo20100818125042.pdf. Acesso em: 15 jan. 2020).

${ }^{48}$ Nesse sentido, cf.: MARTINS, Sandro Gilbert. A defesa do executado por meio de ações autônomas: defesa heterotópica. 2. ed. São Paulo: Revista dos Tribunais, 2005, p. 239; MIZRAHI, Gustavo José. O cabimento das chamadas defesas heterotópicas do executado. Revista Eletrônica de Direito Processual, Rio de Janeiro, v. 12, n. 12, 2013, p. 225. Disponível em: https://www.epublicacoes.uerj.br/index.php/redp/article/view/8679/6555. Acesso em: 30 out. 2014; THEODORO JÚNIOR, Humberto. Primeiras observações sobre o projeto do novo Código de Processo Civil. Revista Magister de Direito Civil e Processual Civil, Porto Alegre, v. 6, n. 36, p. 5-11, maio/jun. 2010. Disponível em: http://www.rkladvocacia.com/arquivos/artigos/art_srt_arquivo20100818125042.pdf. Acesso em: 15 jan. 2020.

49 A tese de que os embargos do devedor têm natureza jurídica de ação é universal: ASSIS, Araken de. Manual da execução. 19. ed. São Paulo: Revista dos Tribunais, 2017, p. 1621; BELTRAME, José Alonso. Dos embargos do devedor. 2. ed. São Paulo: Saraiva, 1983, p. 6-7; LIEBMAN, Enrico Tullio. Processo de execução. 4. ed. São Paulo: Saraiva, 1980, p. 216; LUCON, Paulo Henrique dos Santos. Embargos à execução. São Paulo: Saraiva, 1996, p. 84; MOURA, Mário Aguiar. Embargos do devedor. 5. ed. Rio de Janeiro: Aide, 1986, p. 12; NEVES, Daniel Amorim Assumpção. Manual de Direito Processual Civil. 10. ed. Salvador: JusPodivm, 2018, p. 1340; OLIVEIRA, Antônio Cláudio Mariz de. Embargos do devedor. São Paulo: José Bushatsky, 1977, p. 51; PONTES DE MIRANDA, Francisco Cavalcanti. Comentários ao Código de Processo Civil. Rio de Janeiro: Forense, 1974, p. 4; THEODORO JÚNIOR, Humberto. Curso de Direito 
Revista Eletrônica de Direito Processual - REDP.

Rio de Janeiro. Ano 15. Volume 22. Número 2. Maio a Agosto de 2021

Periódico Quadrimestral da Pós-Graduação Stricto Sensu em Direito Processual da UERJ

Patrono: José Carlos Barbosa Moreira (in mem.). ISSN 1982-7636. pp. 619-647

www.redp.uerj.br

garantia constitucional do direito de agir ( $\mathrm{CF}$, art. 5. ${ }^{\circ}$, inciso $\left.\mathrm{XXXV}\right)$, corolário da garantia inviolável do Estado Democrático de Direito.

Os embargos, como a ação anulatória, têm natureza jurídica de ação porque veiculam um objeto litigioso próprio, cuja decisão fará coisa julgada material. A ação anulatória, tal qual os embargos, constitui o exercício do direito de defesa, porque deduz matérias de defesa que o devedor deduziria nos embargos, mas em outro momento procedimental.

Sobre essa última afirmação, contudo, uma observação deve ser feita.

Diz o artigo 16, § 2. ${ }^{\circ}$, da Lei n. ${ }^{\circ}$ 6.830/1980 que, nos embargos à execução físcal, "o executado deverá alegar toda matéria útil à defesa". Evidentemente, as matérias deduzíveis na ação anulatória são apenas aquelas que visam atingir o direito consubstanciado no título, devendo-se se excluir, a princípio, as matérias eminentemente processuais, seja porque podem ser arguidas, a qualquer tempo, na própria execução fiscal, independentemente de embargos, seja porque, após o término da ação executiva, opera-se sobre elas o fenômeno da preclusão endoprocessual.

De qualquer modo, a ação anulatória constitui uma defesa heterotópica, veiculando o mesmo conteúdo e tendo a mesma finalidade e natureza jurídica dos embargos à execução fiscal, sendo apenas ajuizada fora do momento ou da oportunidade desses embargos. Esse entendimento está em consonância com o próprio STJ, que já decidiu:

Nada impede, outrossim, que o devedor se antecipe à execução e promova, em caráter preventivo, pedido de nulidade do título ou a declaração de inexistência da relação obrigacional. 2. Ações dessa espécie têm natureza idêntica à dos embargos do devedor, e quando os antecedem, podem até substituir tais embargos $^{50}$.

Processual Civil. 51. ed. Rio de Janeiro: Forense, 2018. v. 3, p. 684. Versão digital. Na doutrina italiana: GARBAGNATI, Edoardo. Opposizione. Turim: Utet, 1965, p. 1069; SATTA, Salvatore. Diritto processuale civile. 9. ed. Pádua: Cedam, 1981, p. 714-715. Na doutrina portuguesa: MENDES, João de Castro. Acção executiva. Lisboa: AAFDL, 1980, p. 56-57.

${ }^{50}$ STJ. CC 38.045 MA 2003/0001837-1. Relatora: Min. Eliana Calmon. Relator para o acórdão: Min. Teori Albino Zavascki. Julgado em: 12/11/2003. DJ 09/12/2003, grifo nosso. Cf ainda: “[...] 1. Se é certo que a propositura de qualquer ação relativa ao débito constante do título não inibe o direito do credor de promoverlhe a execução $\left(\mathrm{CPC}\right.$, art. 585, § $1^{\circ}$ ), o inverso também é verdadeiro: o ajuizamento da ação executiva não impede que o devedor exerça o direito constitucional de ação para ver declarada a nulidade do título ou a inexistência da obrigação, seja por meio de embargos (CPC, art. 736), seja por outra ação declaratória ou desconstitutiva. Nada impede, outrossim, que o devedor se antecipe à execução e promova, em caráter preventivo, pedido de nulidade do título ou a declaração de inexistência da relação obrigacional. 2. Ações dessa espécie têm natureza idêntica à dos embargos do devedor e, quando os antecedem, podem até substituir tais embargos, já que repetir seus fundamentos e causa de pedir importaria litispendência” (STJ (1. Turma). 
Revista Eletrônica de Direito Processual - REDP.

Rio de Janeiro. Ano 15. Volume 22. Número 2. Maio a Agosto de 2021

Periódico Quadrimestral da Pós-Graduação Stricto Sensu em Direito Processual da UERJ

Patrono: José Carlos Barbosa Moreira (in mem.). ISSN 1982-7636. pp. 619-647

www.redp.uerj.br

Assim, constituindo a ação anulatória a mesma defesa dos embargos, sendo apenas ajuizada fora da oportunidade deles, trata-se, essencialmente, de embargos ajuizados em outro momento, conforme já se posicionou o STJ. Como corolário, deve ser aplicado o mesmo tratamento jurídico a ambos. Não se pode conceber os embargos à execução físcal submetidos à prévia garantia do juízo como condição para o seu processamento. A inexigibilidade da garantia do juízo deve ser uniforme, considerando que os embargos e a ação anulatória possuem a mesma natureza jurídica, veiculando o mesmo conteúdo.

\section{CONCLUSÃO}

O STJ assentou o entendimento de que a dispensa da garantia como condicionante dos embargos prevista no artigo 914 do CPC de 2015 não se aplica à LEF, uma vez que o artigo $16, \S 1^{\circ}$, da LEF exige expressamente a garantia para a apresentação dos embargos.

Tal posicionamento foi assentado no julgamento do REsp 1272827/PE, em 2013, analisado sob a sistemática dos recursos repetitivos, ainda sob a égide do CPC de 1973, quando a Corte Superior proferiu o entendimento de que, para admitir a exigência da garantia da execução para o processamento dos embargos à execução, aplica-se a regra da especialidade do artigo 16 da LEF, mas, para exigir a atribuição do efeito suspensivo, deve-se aplicar o CPC (art. 739-A, § 1. ${ }^{\circ}$, do CPC/1973, incluído pela Lei n. ${ }^{\circ} 11.382 / 2006$ ).

A primeira ponderação que se faz é que o efeito suspensivo é apenas um dos aspectos da estrutura jurídica dos embargos do devedor, não podendo ser compreendido fora do contexto integral desse instituto. A opção do legislador de dar ou não efeito suspensivo aos embargos não pode ser dissociada da exigência de prévia garantia do juízo. Tanto isso é verdade que, quando a Lei n. ${ }^{\circ}$ 11.362/2006 retirou dos embargos o efeito suspensivo automático, como regra (art. 739-A do CPC/1973), incontinenti retirou também desses embargos a exigência da prévia garantia de juízo (art. 736 do CPC/1973).

Logo, a garantia do juízo, o momento de sua oposição, seus pressupostos e os efeitos decorrentes devem ser compreendidos dentro do contexto geral e sistemático do

REsp 754.586/RS. Relator: Min. Teori Albino Zavascki. Julgado em 21/03/2006. REPDJ 12/06/2006, p. 447, DJ 03/04/2006, p. 263). Cf. também: STJ (1. Turma). REsp 799.364/SP. Relator: Min. Teori Albino Zavascki. Julgado em 13/12/2005. DJ 06/02/2006, p. 230. 
Revista Eletrônica de Direito Processual - REDP.

Rio de Janeiro. Ano 15. Volume 22. Número 2. Maio a Agosto de 2021

Periódico Quadrimestral da Pós-Graduação Stricto Sensu em Direito Processual da UERJ

Patrono: José Carlos Barbosa Moreira (in mem.). ISSN 1982-7636. pp. 619-647

www.redp.uerj.br

instituto dos embargos à execução, que tampouco podem ser dissociados do procedimento de defesa - regra geral aplicável a qualquer execução -, uma vez que a defesa na execução fiscal jamais decorreu das peculiaridades da relação entre o contribuinte e a Fazenda Pública, mas decorre da mera repetição da regra já prevista no regramento instituído pelo CPC de 1973.

Não incide, portanto, no procedimento de defesa à execução fiscal, o princípio da especialidade, pois não se trata da criação de um procedimento específico para atender as especificidades da relação material entre o fisco e o contribuinte. A opção do legislador pela nova sistemática de defesa na execução - retirando-lhe o efeito suspensivo automático, como regra - não é uma peculiaridade da execução regulada no CPC, mas deve ser compreendida dentro do contexto geral e sistemático do instituto dos embargos à execução aplicável também à execução fiscal, não havendo uma especificidade que justifique sua manutenção após as inovações legislativas para dispensar a garantia do juízo para a oposição de embargos.

Além disso, o posicionamento do STJ ignora toda a carga valorativa das normas constitucionais trazida pelo CPC de 2015. O fenômeno do neoconstitucionalismo não é isolado no direito processual, mas traz premissas metodológicas e valorativas que se espraiam para todo o ordenamento jurídico, inclusive na aplicação das normas infraconstitucionais anteriores à Constituição, como a Lei de Execução Fiscal (de 1980).

Não se pode, sob o manto de que as normas foram editadas em momento anterior à Constituição, ignorar que sobre elas incide o fenômeno do neoprocessualismo, o qual traz uma nova concepção de processo baseado no reconhecimento da força normativa da Constituição e resulta da constitucionalização dos direitos e garantias processuais.

Logo, embora o STJ tenha invocado o princípio da especialidade da LEF para manter a garantia como condicionante dos embargos, não pode desprezar, por certo, a carga valorativa das normas constitucionais trazidas pelo Código atual, devendo ser sopesadas as novas premissas que resultam da constitucionalização dos direitos e garantias processuais.

A necessidade de interpretação da execução fiscal à luz das normas fundamentais trazidas pelo CPC é uma expressão da teoria do diálogo das fontes, podendo-se afirmar que 
Revista Eletrônica de Direito Processual - REDP.

Rio de Janeiro. Ano 15. Volume 22. Número 2. Maio a Agosto de 2021

Periódico Quadrimestral da Pós-Graduação Stricto Sensu em Direito Processual da UERJ

Patrono: José Carlos Barbosa Moreira (in mem.). ISSN 1982-7636. pp. 619-647

www.redp.uerj.br

a dispensa da garantia do juízo como condicionante dos embargos, prevista no artigo 914 do CPC/2015, por ser norma genérica mais consentânea aos valores constitucionais, prefere à norma especial do artigo $16, \S 1 .^{\circ}$, da LEF, que exige a garantia do juízo para o manejo dos embargos à execução.

Há de se aplicar, portanto, à LEF a carga valorativa das normas constitucionais trazidas pelo CPC de 2015, especificamente em relação aos embargos à execução fiscal, considerando que a exigência da prévia garantia do juízo para a oposição desses embargos não se coaduna com os princípios constitucionais de acesso à justiça e do devido processo legal previstos entre os direitos fundamentais no Estado Democrático de Direito.

Por fim, o posicionamento consolidado pelo STJ, admitindo que os embargos à execução fiscal somente podem ser manejados após a garantia do juízo, vai de encontro ao princípio da especialidade, à garantia do direito de defesa e ao princípio constitucional de acesso à justiça, mas, principalmente, é incongruente com o posicionamento assentado pelo STF, que já decidiu (Súmula Vinculante 28) pela inconstitucionalidade da exigência do depósito prévio como requisito de admissibilidade de ação judicial na qual se pretenda discutir a exigibilidade do crédito tributário.

Constituindo a ação anulatória a mesma defesa dos embargos, sendo apenas ajuizada fora da oportunidade deles, trata-se, essencialmente, de embargos ajuizados em outro momento, conforme já se posicionou o próprio STJ, devendo, portanto, ser aplicado o mesmo tratamento jurídico a ambos. A inexigibilidade da garantia do juízo deve ser uniforme, visto que os embargos e a ação anulatória possuem a mesma natureza jurídica, veiculando o mesmo conteúdo.

De tudo exposto, há de se rechaçar o posicionamento assentado no STJ, que exige a garantia da execução para o processamento dos embargos à execução, pois vai de encontro ao princípio da especialidade, à carga valorativa das normas constitucionais trazidas com o CPC de 2015 e ao posicionamento da Súmula Vinculante 28 do STF.

\section{REFERÊNCIAS}


Revista Eletrônica de Direito Processual - REDP.

Rio de Janeiro. Ano 15. Volume 22. Número 2. Maio a Agosto de 2021

Periódico Quadrimestral da Pós-Graduação Stricto Sensu em Direito Processual da UERJ

Patrono: José Carlos Barbosa Moreira (in mem.). ISSN 1982-7636. pp. 619-647

www.redp.uerj.br

ACOSTA SÁNCHEZ, José. Formación de la Constitución y jurisdicción constitucional:

fundamentos de la democracia constitucional. Madrid: Tecnos, 1998.

ASSIS, Araken de. Manual da execução. 19. ed. São Paulo: Revista dos Tribunais, 2017.

BARROSO, Luís Roberto. Curso de Direito Constitucional Contemporâneo. São Paulo:

Saraiva, 2009a.

BARROSO, Luís Roberto. O direito constitucional e a efetividade de suas normas: limites e possibilidades da Constituição brasileira. 9. ed. Rio de Janeiro: Renovar, 2009b.

BELTRAME, José Alonso. Dos embargos do devedor. 2. ed. São Paulo: Saraiva, 1983.

BENJAMIN, Antonio Herman; MARQUES, Claudia Lima. A teoria do diálogo das fontes

e seu impacto no Brasil: uma homenagem a Erik Jayme. Revista de Direito do Consumidor, São Paulo, v. 27, n. 115, p. 21-40, jan./fev. 2018.

BERMUDES, Sergio. A reforma do Código de Processo Civil. 2. ed. São Paulo, Saraiva, 1996.

BONAVIDES, Paulo. Curso de Direito Constitucional. São Paulo: Malheiros, 2006.

BUENO, Cassio Scarpinella. O "modelo constitucional do direito processual civil": um paradigma necessário de estudo do direito processual civil e algumas de suas aplicações. Revista de Processo, São Paulo, v. 33, n. 161, p. 261-270, jul. 2008.

CAMBI, Eduardo. Neoconstitucionalismo e neoprocessualismo. Revista do Programa de Pós-Graduação em Direito da Universidade Federal da Bahia, Salvador, v. 2, n. 17, p. 93-130, 2008. Homenagem ao Professor Luiz de Pinho Pedreira. Disponível

em: https://vitorfreitas.goias.ufg.br/up/662/o/Eduardo_Cambi_Neoconstitucionalismo_e_ Neoprocessualismo.pdf. Acesso em: 2 jan. 2020.

CANOTILHO, José Joaquim Gomes. Direito constitucional e teoria da constituição. 6. ed. Coimbra: Almedina, 2003.

CARBONELL, Miguel. Neoconstitucionalismo. Madrid: Trotta, 2009.

COMOGLIO, Luigi Paolo. Garanzie costituzionali e "giusto processo": modelli a confronto. Revista de Processo, São Paulo, v. 23, n. 90, p. 95-150, abr./jun. 1998.

CUNHA, Leonardo Carneiro da. A Fazenda Pública em juízo. 11. ed. São Paulo: Dialética, 2013. 
Revista Eletrônica de Direito Processual - REDP.

Rio de Janeiro. Ano 15. Volume 22. Número 2. Maio a Agosto de 2021

Periódico Quadrimestral da Pós-Graduação Stricto Sensu em Direito Processual da UERJ

Patrono: José Carlos Barbosa Moreira (in mem.). ISSN 1982-7636. pp. 619-647

www.redp.uerj.br

DIDIER JR., Fredie. Curso de Direito Processual Civil: introdução ao direito processual civil, parte geral e processo de conhecimento. 19. ed. Salvador: JusPodivm, 2017.

FARIA, Marcio Gustavo Senra. Interações entre o Novo CPC e a LEF: a Teoria do Diálogo das Fontes no processo de execução fiscal. In: DUARTE, Fernanda; BOMFIM, Gilson; MURAYAMA, Janssen (org.). A LEF e o Novo CPC: reflexões e tendências, o que ficou e o que mudará. Rio de Janeiro: Lumen Juris, 2016. p. 53-69.

GARBAGNATI, Edoardo. Opposizione. Turim: Utet, 1965.

HESSE, Konrad. A força normativa da constituição. Porto Alegre: Safe, 1991.

LEAL, Pastora do Socorro Teixeira. "Diálogo" das fontes e responsabilidade civil: um aporte para a formulação do conceito de dano de conduta. In: LOURENÇO, Cristina Silvia Alves; BARBALHO, Lucas de Siqueira Mendes; RODRIGUES, Victor Russo Fróes; NÓVOA, Victor Siqueira Mendes de (org.). Estudos de Ciências Criminais e Filosofia do Direito: Homenagem ao Emérito Professor Ney Siqueira Mendes. Rio de Janeiro: Lumen Juris, 2019. p. 243-272.

LIEBMAN, Enrico Tullio. Processo de execução. 4. ed. São Paulo: Saraiva, 1980.

LORENZONI, Brunno; ROCHA, Sergio André. O incidente de desconsideração da personalidade jurídica e sua aplicação no processo de execução fiscal. In: DUARTE, Fernanda; BOMFIM, Gilson; MURAYAMA, Janssen (org.). A LEF e o Novo CPC: reflexões e tendências, o que ficou e o que mudará. Rio de Janeiro: Lumen Juris, 2016. p. 210-224.

LUCON, Paulo Henrique dos Santos. Embargos à execução. São Paulo: Saraiva, 1996.

MACHADO, Hugo de Brito. Execução fiscal e ação anulatória. Revista de Processo, São Paulo, v. 6, n. 24, p. 110-116, out./dez. 1981.

MARTINS, Sandro Gilbert. A defesa do executado por meio de ações autônomas: defesa heterotópica. 2. ed. São Paulo: Revista dos Tribunais, 2005.

MENDES, João de Castro. Acção executiva. Lisboa: AAFDL, 1980.

MITIDIERO, Daniel. Colaboração no processo civil: pressupostos sociais, lógicos e éticos. São Paulo: Revista dos Tribunais, 2009.

MIZRAHI, Gustavo José. O cabimento das chamadas defesas heterotópicas do executado. Revista Eletrônica de Direito Processual, Rio de Janeiro, v. 12, n. 12, p. 217-241, 
Revista Eletrônica de Direito Processual - REDP.

Rio de Janeiro. Ano 15. Volume 22. Número 2. Maio a Agosto de 2021

Periódico Quadrimestral da Pós-Graduação Stricto Sensu em Direito Processual da UERJ

Patrono: José Carlos Barbosa Moreira (in mem.). ISSN 1982-7636. pp. 619-647

www.redp.uerj.br

2013. Disponível em: https://www.e-

publicacoes.uerj.br/index.php/redp/article/view/8679/6555. Acesso em: 30 out. 2014.

MOURA, Mário Aguiar. Embargos do devedor. 5. ed. Rio de Janeiro: Aide, 1986.

NERY JUNIOR, Nelson. Princípios do processo na Constituição Federal: processo civil, penal e administrativo. 11. ed. São Paulo: Revista dos Tribunais, 2012. v. 1.

NERY JUNIOR, Nelson; NERY, Rosa Maria de Andrade. Código de Processo Civil comentado. 16. ed. São Paulo: Revista dos Tribunais, 2016.

NEVES, Daniel Amorim Assumpção. Manual de Direito Processual Civil. 10. ed. Salvador: JusPodivm, 2018.

OLIVEIRA, Antônio Cláudio Mariz de. Embargos do devedor. São Paulo: José Bushatsky, 1977.

PACHECO, José da Silva. Comentários à nova Lei de Execução Fiscal. São Paulo: Saraiva, 1981.

PONTES DE MIRANDA, Francisco Cavalcanti. Comentários ao Código de Processo Civil. Rio de Janeiro: Forense, 1974.

POZZOLO, Susanna. Neoconstitucionalismo y especificidad de la interpretación constitucional. Doxa: Cuadernos de Filosofía del Derecho, Buenos Aires, n. 21, p. 339-353, 1998. Disponível em: http://www.cervantesvirtual.com/obra/n-21---1998/. Acesso em: 10 abr. 2017.

RODRIGUES, Rafael de Oliveira. O abuso do processo por intermédio da defesa heterotópica. Revista Eletrônica de Direito Processual, Rio de Janeiro, v. 8, n. 8, p. 850-867, 2011. Disponível em: https://www.epublicacoes.uerj.br/index.php/redp/article/view/20846/15122. Acesso em: 30 out. 2012.

SANTIAGO, Julio Cesar. A influência do Novo CPC na cobrança judicial do crédito tributário. In: DUARTE, Fernanda; BOMFIM, Gilson; MURAYAMA, Janssen. A LEF e o Novo CPC: Reflexões e tendências, o que ficou e o que mudará. Rio de Janeiro: Lumen Juris, 2016. p. 21-30.

SATTA, Salvatore. Diritto processuale civile. 9. ed. Pádua: Cedam, 1981.

SHIMURA, Sergio Seiji. Título executivo. 2. ed. São Paulo: Método, 2005. 
Revista Eletrônica de Direito Processual - REDP.

Rio de Janeiro. Ano 15. Volume 22. Número 2. Maio a Agosto de 2021

Periódico Quadrimestral da Pós-Graduação Stricto Sensu em Direito Processual da UERJ

Patrono: José Carlos Barbosa Moreira (in mem.). ISSN 1982-7636. pp. 619-647

www.redp.uerj.br

SILVA, Luiz Octavio Pinheiro Carvalho da; SCIOLLA, Daniella de Jesus Silva. Execução fiscal e novo Código de Processo Civil: haverá um processo realmente justo? In: DUARTE, Fernanda; BOMFIM, Gilson; MURAYAMA, Janssen (org.). A LEF e o Novo CPC: reflexões e tendências, o que ficou e o que mudará. Rio de Janeiro: Lumen Juris, 2016. p. 7-20.

SZKLAROWSKY, Leon Frejda. Execução fiscal. Brasília, DF: Ministério da Fazenda, 1984.

THEODORO JÚNIOR, Humberto. Curso de Direito Processual Civil. 51. ed. Rio de Janeiro: Forense, 2018. v. 3. Versão digital.

THEODORO JÚNIOR, Humberto. Execução fiscal. 13. ed. São Paulo: Saraiva, 2016.

THEODORO JÚNIOR, Humberto. Primeiras observações sobre o projeto do novo Código de Processo Civil. Revista Magister de Direito Civil e Processual Civil, Porto Alegre, v. 6, n. 36, p. 5-11, maio/jun. 2010. Disponível em: http://www.rkladvocacia.com/arquivos/artigos/art_srt_arquivo20100818125042.pdf. Acesso em: 15 jan. 2020. 